\title{
In memoriam: Alicja Stach (1951-2009): a dedicated aerobiologist
}

\author{
D. Stępalska $\cdot$ K. Szczepanek $\cdot$ D. Myszkowska
}

Received: 12 July 2010/Accepted: 21 September 2010/Published online: 26 October 2010

(C) Springer Science+Business Media B.V. 2010

Alicja Stach was born on February 17, 1951, in Szamarzewo, Poland. In 1968, she entered the Adam Mickiewicz University of Poznań, Faculty of Biology and Earth Sciences and graduated in 1974 with a Master of Sciences degree. Immediately following graduation from the University, Alicja's professional life began at the Institute of Geography. In 1980, she started to study palynology. In 1989, she was assigned to the Department of Geomorphology under the leadership of Professor Stefan Kozarski where she continued her work as a palynologist. First training in aerobiological monitoring, Alicja completed at the Institute of Geology in Oslo in 1991. In 1994, she participated in the next aerobiological course under the leadership of Professor Kazimierz Szczepanek at the Jagiellonian University in Cracow. Alicja obtained further aerobiological knowledge at many European Basic Aerobiological Courses (Leiden, The Netherlands 1995, Worcester, England 1997, Cordoba, Spain 1999) and International Advanced Courses (Riva del Garda, Italy 1998, Mt. Cimone,

D. Stępalska $(\bowtie) \cdot$ K. Szczepanek

Institute of Botany, Jagiellonian University, Kopernika 27, 31-501 Kraków, Poland

e-mail: stepalska@op.pl

D. Myszkowska

Department of Clinical and Environmental Allergology, Medical College Jagiellonian University, Śniadeckich 10, 31-531 Kraków, Poland
Italy 2000). In 2002, she enjoyed her Ph.D. degree in aerobiology obtained at the Jagiellonian University in Cracow. Two years later, making a great effort, Alicja created and developed the Laboratory of Aeropalynology at the Adam Mickiewicz University in Poznań that went on to attain a high scientific level and an international reputation.

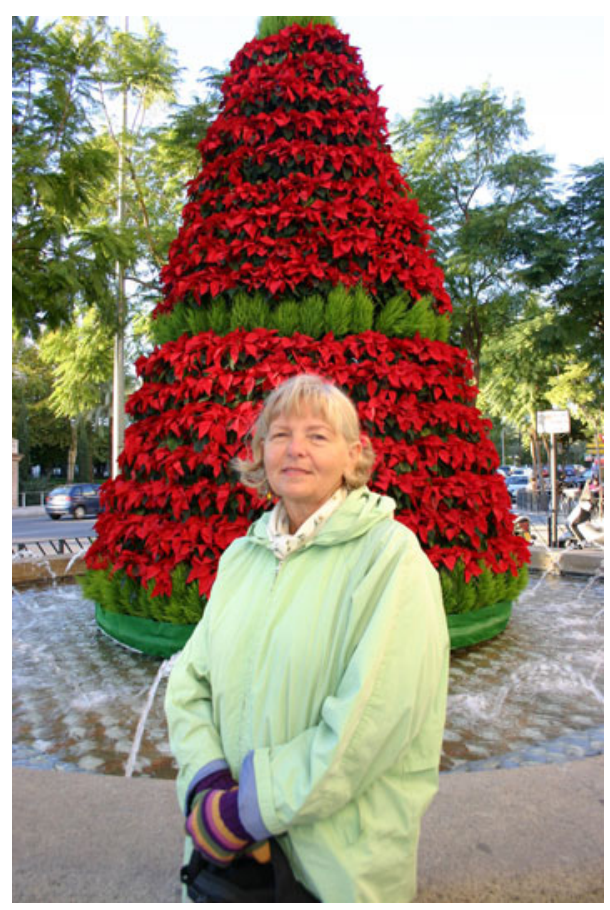

Fig. 1 Scientific stay in Cordoba, 2006 (AEROTOP) 
The role of Alicja in aerobiology was very important at a national level. She was an Executive Committee member of the Polish Botanical Society (Section of Aerobiology). Thanks to Alicja's strenuous work, the Polish Aerobiology Network has grown quickly and has included many university centres involved in this discipline.

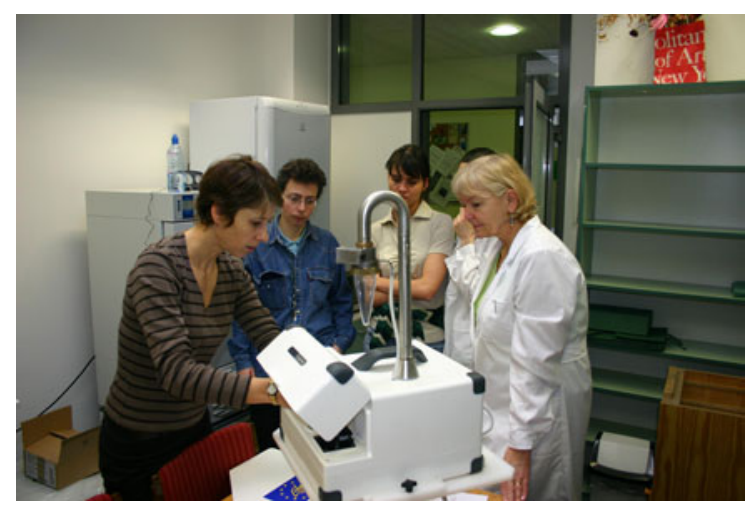

Fig. 2 Laboratory of Aeropalynology in Poznań, Poland

Alicja co-operated in organizing the 6th European Basic Aerobiological Course in Poznań in 2003, and she was invited by the teacher group to be a teacher in the next two courses (France 2005, Serbia 2007). She was a coordinator of a 4-year European Project, the European Union Marie Curie Actions Development Scheme (AEROTOP), which allowed her to open her Laboratory for European colleagues. Also, the Laboratory of Aeropalynology profited from this transfer of knowledge. Partner universities in Cordoba and Worcester received her and her colleagues in their laboratories, and all of them profited from this collaboration.

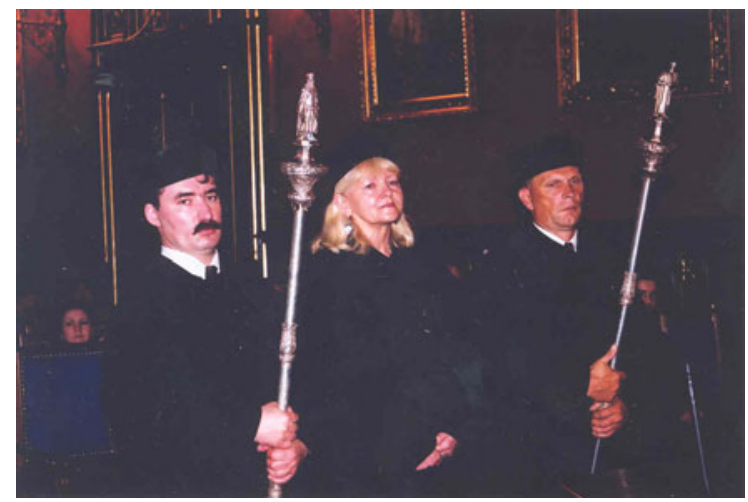

Fig. 3 Doctors promotion in Cracow, Poland, 2002
Alicja was an outstanding member of the international aerobiological community. She was a founder member of the European Aerobiology Society, a Polish representative in the Management Committee of the European Science Foundation COST Action ES0603 "Assessment of production, release, distribution and health impact of allergenic pollen in Europe" (EUPOL) and an Executive Committee member "at large" of the International Association of Aerobiology. She was very active and full of energy. She took part in national and international meetings and congresses presenting results of her scientific research and being an active member of scientific committees at congresses and conferences. She was a great local patriot. It was her initiative to design the Pollen Guide-Book for Great Poland in which pollen information is available for allergic people.

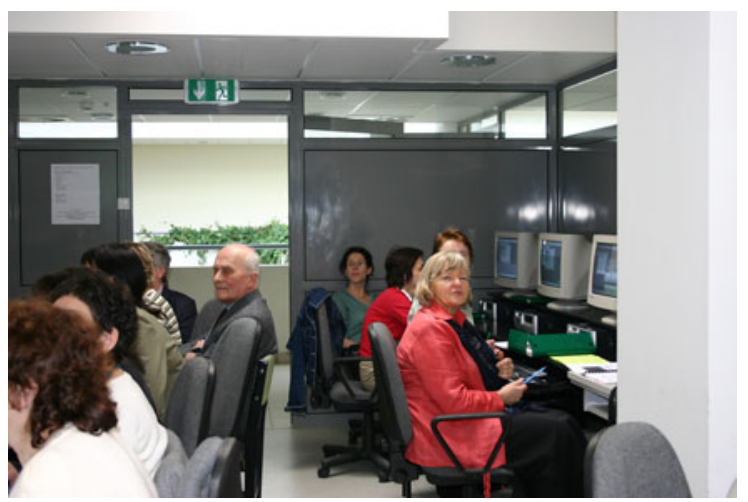

Fig. 4 Workshop in frame of AEROTOP, Poznań, Poland, 2006

Aerobiology and the Laboratory were always important things for her, but she also knew how to enjoy family life. She was always ready to discuss problems and to help colleagues and students in their work. Alicja was an open, friendly person, very optimistic, cheerful and warm-hearted. She had a natural ability for gathering friends around her. Alicja aimed high in her life, and in spite of different difficulties, she always reached her welldefined purposes. It is very painful that her time is over and she cannot enjoy the results of her hard work. 


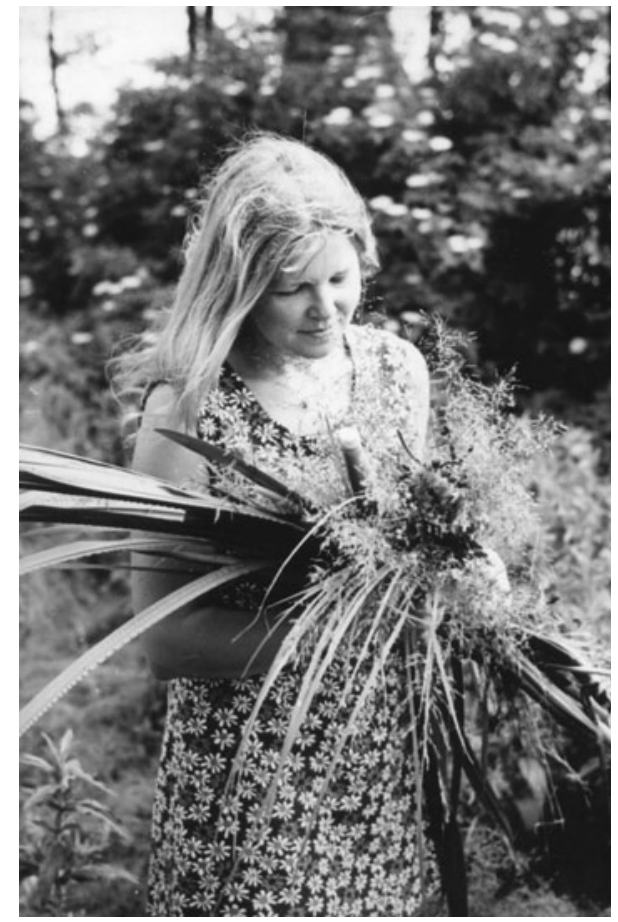

Fig. 5 Poznań, Poland, 1985

\section{Some published articles}

Stach A. (1987) Wyniki badań palinologicznych młodoholoceńskiej historii $\mathrm{w}$ osadach rynny jeziornej Baranówka pod Poznaniem. Badania Fizjograficzne nad Polskạ Zachodnią, Ser. A: Geografia Fizyczna, 37: 163-170

Szczepanek K., Harmata K., Kasprzyk I., Stach A., Stępalska D. (1996) The relation between the pollen content in the air in 1995 and landscape differentiation within Poland. Mak. Med. Preglad 1996; 50 (Supplement 23), s. 91

Stach A., Silny W. (1996) Pollen calendar for selected allergenic taxa for Poznań and neighbourhood (1992-1996), Annals of Agricultural and Environmental Medicine, vol. 3, No 2, 149-151

Stach A. (1996) Pollen fall of certain allergenic plants in Poznań 1992-1995. Contribution to compilation of pollen calendar for Poznań and surrounding area. Annals of Agricultural and Environmental Medicine, vol. 3. No 2, 99-108 Hofman T., Wykrętowicz G., Stach A., Springer E., Kolasińska B., Ossowski M. (1996) A multicentre analysis of a population of patients with newly diagnosed pollinosis in Poznań, Poland, in the year 1995. Annals of Agricultural of Environmental Medicine, vol. 3, No 2, 171-177 Silny W., Siatecka D., Stach A. (1997) Stężenia swoistych IgE w surowicy badane metodą CAP System na tle pomiarów palinologicznych w Poznaniu w 1996 r. International review of allergology \& clinical immunology vol. III, suppl. 2, medpress

Juvigne E., Stach-Czerniak A. (1998) Etude sedimentologique et palynologique des depots lacustres tardiglaciaires et holocenes du gour de Tazenat (Massif Central, France), Quaternaire, 9(1), 1998, pp. $15-23$

Stach A., Silny W. (1999) Pyłek z. dalekiego transportu w aeroplanktonie Poznania w latach 1995-1997 (wybrane taksony alergogenne). Bibliotheca Fragmenta Agronomica. 6: 209-216.

Stępalska D., Harmata K., Kasprzyk I., Myszkowska D., Stach A. (1999) Occurrence of airborne Cladosporium and Alternaria spores in Southern and Central Poland in 1995-1996. Aerobiologia 15: 39-47

Stach A. (2000) Variation in pollen concentration of the most allergenic taxa in Poznan (Poland), 1995-1996. Aerobiologia 16: 63-68

Stach A. (2000) Wpływ temperatury, opadu i wiatru na wahania stężenia pyłku wybranych taksonów alergogennych w Poznaniu w latach 1995-1999. Alergia Astma Immunologia (suplement). 5, 287

Kasprzyk I., Harmata K., Myszkowska D., Stach A., Stępalska D. (2001) Diurnal variation of chosen airborne pollen at five sites in Poland. Aerobiologia 17 (4), 327-345

Stach A., Kluza-Wieloch M., Zientarska A. (2004) The phenology of flowering and airborne pollen concentrations of selected trees in Poznań, (Poland), 1995-1997. Pollen vol. 14, 346-347

Kasprzyk I., Uruska A., Szczepanek K., Latałowa M., Gaweł J., Harmata K., Myszkowska D., Stach A., Stępalska D. (2004) Regional differentiation in the dynamics of the pollen seasons of Alnus, Corylus and Fraxinus in Poland (preliminary results). Aerobiologia; 20; 141-151

Emberlin J., Detandt m., Gehrig R., Jaeger S., Laadi M., Norald N., Rantio-Lehtimaki, Stach A. (2004) The impact of recent climatic changes in 
Europe on the start of Betula (birch) pollen seasons in seven countries. Pollen 14, 89-90,

Bugajny A., Snopkiewicz M., Pietraszewska-Pająk M., Stach A., Filipiak M. (2005) On the Microbiological Quality of the Outdoor Air in Poznan, Poland. Polish Journal of Environmental Studies vol.14, no. 3, 287-293

Emberlin J., Detandt M., Gehrig R., Jaeger S., Laaidi M., Nolard N., Rantio-Lehtimäki A., Stach A. (2005) Changes in the start of Betula spp. pollen seasons in seven European countries in relation to spring temperatures over 22 Years. Annalen der Metorologie 41, vol. 2, 573-576

Stach A., Kasprzyk I. (2005) Metodyka badań zawartości pyłku roślin i zarodników grzybów w powietrzu z zastosowaniem aparatu Hirsta. Bogucki Wydawnictwo Naukowe ISBN 83-60247-110, 1-78

Stach A., Galan C., Emberlin J., Garcia Mozo H., Prieto Baena J.C., Bustos Delgado I. (2005) European Project-Aerobiology to Poznań (AEROTOP). Allegro Journal 14, 278-279

Stach A., Garcia-Mozo H., Prieto-Baena J.C., Czarnecka-Operacz M., Jenerowicz D., Silny W., Galan C. (2006) Prevalence of Artemisia Species Pollinosis in Western Poland: Impact of Climatic Change on Aerobiological Trends, 1995-2004. Journal Investig Allergol Clin Immunol, 16(7) Emberlin J., Smith M., Close R., Adams-Groom B. (2006) Changes in the pollen seasons of the early flowering trees Alnus spp. and Corylus spp. in Worcester, United Kingdom, 1996-2005. International Journal Biometeorol, DOI 10.1007/s00484006-0059-2 (MNiI—pkt 20, IF-0,924)

Stach A., Kluza-Wieloch M., Zientarska A. (2006) The phenology of flowering and fluctuations of airborne pollen concentrations of selected trees in Poznań, 2003-2004. Acta Agrobotanica, 59(1), 301-308

Stach A. (2006) Is pollen of ragweed (Ambrosia sp.) a threat to people with allergies in the Wielkopolska region? Biodiversity: Research and Conservation (BRC)

Stach A., Prieto Baena J. C. (2006) Seasonal fluctuations in pollen concentrations of allergenic plants in the air of Poznań in 2004. Biodiversity: Research and Conservation (BRC)

Kasprzyk I., Myszkowska D., Piotrowska K., Puc M., Smith M., Stach A., Stepalska D., Uruska A.,
Weryszko-Chmielewska E. (2007) Aerobiologia. Podręcznik dla studentów. Wydawnictwo Akademii Rolniczej w Lublinie

Stach A., Smith M., Sjoth C. A., Brandt J. (2007) Examining Ambrosia pollen episodes at Poznań (Poland) using back-trajectory analysis. Int $\mathrm{J}$ Biometeorol; 51, 275-286

Smith M., Emberlin J., Stach A., CzarneckaOperacz M., Jenerowicz D., Silny W. (2007) Regional importance of Alnus pollen as an aeroallergen: a comparative study of Alnus pollen counts from Worcester (UK) and Poznań (Poland). Ann Agric Environ Med, 14, 123-128

Skjoth C. A., Sommer J., Stach A., Smith M., Brandt J. (2007) The long-range transport of birch (Betula) pollen from Poland and Germany causes significant pre-season concentrations in Denmark. Clinical and Experimental Allergy, 37, 1204-1212 Stach A., Garcia-Mozo H., Prieto-Baena J. C., Czarnecka-Operacz M., Jenerowicz D., Silny W, Galan C. (2007) Prevalence of Artemisia Species Pollinosis in Western Poland: Impact of Climatic Change on Aerobiological Trends, 1995-2004. Journal Investig Allergol Clin Immunol, 17(1): 39-47

Kalinovych N., Stach A., Chernetsky M., Uruska A., Nowak M., Szymańska A. (2007) Comparative characteristics of pollen fall of allergenic plants in Wielkopolska region (Poland) and in Lviv city (Ukraine). Studia Biologica 2007; tom 1, nr 1: 73-86

Szopińska D., Tylkowska K., Stach A. (2007) Relationships between seed development stage, germination, occurrence and location of fungi in oilseed rape (Brassica Napus ssp. Oleifera L.) seeds and the Presence of Alternaria and Cladosporium spp. spores in the air. Electronic Journal of Polish Agricultural Universities Vol. 10(4)

Smith M., Skjoth C. A., Myszkowska D., Uruska A., Puc M., Stach A., Balwierz Z., Chlopek K., Piotrowska K., Kasprzyk I., Brandt J. (2008) Longrange transport of Ambrosia pollen to Poland, Agricultural and Forest Meteorology 148, 1402-1411

Stach A., Smith M., Prieto Baena J. C., Emberlin J. (2008) Long-term and short-term forecast models for Poaceae (grass) pollen in Poznań, Poland, constructed using regression analysis, Environmental and Experimental Botany 62, 323-332 
Stach A., Emberlin J., Smith M., Adams-Groom B., Myszkowska D. (2008) Factors that determine the severity of Betula spp. pollen seasons in Poland (Poznań and Krakow) and the United Kingdom (Worcester and London), Int J Biometeorol 52, 311-321
Alcázar P., Stach A., Nowak M., Galán C. (2009) Comparison of airborne herb pollen types in Córdoba (Southwestern Spain) and Poznan (Western Poland). Aerobiologia 25: 55-63. 